\title{
The Influence of Internal Promotion and Training Incentives on Employee Performance at University of Nairobi
}

\author{
Dorothy Njiraine, $\mathrm{PhD}$ \\ University of Nairobi, Department of Library and Information Science, \\ P.O. Box 30197-00100 Nairobi, Kenya
}

\begin{abstract}
The paper examines the extent to which incentives such as employee training and internal promotion contribute to employee performance, the case of University of Nairobi. The study was descriptive in nature and investigated employee training and internal promotion to assess employee performance at the University of Nairobi. The target population in this study was the non-teaching staff of Nairobi University, whereby stratified sampling technique was applied. The findings of the study revealed that both employee training and internal promotion as human resource management practice enhances performance of employees and enhances organization's competitiveness. A major recommendation is the need to harmonize and integrate internal promotion and training as incentives towards employee improved performance. Further research should be done to explore the role of emerging technology, environment (facility layout, location, and supervision), attitude (character) and other personal (family issues) as other factors that affect employee's performance.
\end{abstract}

Keywords: Human resource management practices, human resource management, training, skills development, internal promotion, employee performance, incentives.

DOI: $10.7176 / \mathrm{EJBM} / 11-14-08$

Publication date:May $31^{\text {st }} 2019$

\section{Introduction and background}

Many organizations undertake different strategies to promote employability, attract, motivate and retain employees in return for employees' continuous commitment and productivity (Ling et al. 2014). Additionally, the success of every organization revolves around the quality of its employees hence, the need to constantly update the employees' knowledge, skills and competencies (Mzimela \& Chikandiwa, 2017). Retaining and motivating human capital is essential for value creation (Coff \& Kryscynski, 2011; Foss, 2011), while promotions serve a matching function as they sort employees into the jobs for which their skills and abilities are best suited (Campbell, 2008). Creating competitive advantage through people requires careful attention to the practices that best leverage these assets. This is by no means through motivation in terms of incentives. As Atambo et al (2013) argues, organizations use incentives to reach certain goals, encourage a certain behavior and team-spirit for collective awards.

According to UNDP (2006) report, incentives and incentive systems are fundamental to developing capacities and translating developed capacities into better performance in organizations. Employee motivation is crucial to Organizations especially in the current dynamic technological environment. Organizations need to maintain their competitive edge by investing in employees' wellbeing in terms of incentives in order to succeed. The United Nations Development Programme (UNDP, 2006) describes incentives as "both the reason for staff to join an organization, and the way an organization rewards and punishes its staff'.Kaiser (2014) argues that incentives are often considered as forms of extrinsic motivation whereby employees tend to perform their jobs well when incentives such as performance pay and bonuses are in place. As Ogutu (2014) contends, the main factors affecting performance in the civil service include low salaries and allowances, lack of equipment and office space, poor compensation, absence of a career-development structure, and poor delegation. The influence of incentives on employee performance with regard to incentive structures, types of incentives and how they are used ranging from wage emoluments, training and promotion procedures and sanctions against poor performance, is in a wanting state (Morgan \& Baser, 2007).

Human resource management (HRM) is contributes to effective organizational performance (Takeuchi et al., 2007; Huselid, 1995). Additionally the HRM functions such as training and development, employee participation, appraisal, rewards, status and security, staffing have been linked to organizational performance outcomes (Datta et al., 2005), which include but not limited to employee skills, motivation, commitment, work quality, performance and opportunities to contribute (Lepak et al., 2006; Liao et al., 2009). Human resources management has diverse definitions, some of which are: a strategic, integrated and coherent approach to the employment, development and well-being of the people in working organizations, while others refer to the process through which management builds the workforce and tries to create the human performances that the organization needs and distinctive approach to employment management which seeks to obtain competitive advantage through the strategic deployment of a highly committed and skilled workforce, using an array of cultural, structural and personnel techniques (Armstrong, 2016:7; Boxall and Purcell, 2016: 7; Storey, 2013). It is clear that human resources management is an important part of today's business management, which incorporates incentives as one of the key 
factors to enhance employees' performance in organizations.

\subsection{Public Higher Education Institutions (HEIs) in Kenya}

Higher Education drives and is driven by globalization in addition to training skilled workers and contributes to the research base and capacity for innovation that determine competitiveness in the knowledge-based global economy while facilitating international collaboration and cross-cultural exchange (OECD 2009). The cross-border flow of ideas, students, faculty and financing coupled with developments in information and communication technology, are changing the environment where higher education institutions function (OECD 2009; Okioga et al. 2014).

By 2017, Kenya had seventy-one (71) universities comprising thirty-five (35) public and thirty-six (36) private universities (CUE 2017). Some of the factors for the rise of universities include but not limited to: emphasis on education by government (Bailey et al, 2013; Nyangau, 2014; World Bank 2017), the need for highly trained and skilled workforce (Kwambai, 2017), quest for education (Onsongo 2007; Republic of Kenya 2006) among others. The universities have to continue to create value to survive this competitive onslaught by recognizing the potential for their employees as a source of competitive advantage (Ubeda-García, et al, 2013: 380; Salas \& Cannon-Bowers, 2001; Kraiger, 2003; Pena \& Villasalero, 2010; Pfeffer, 1994), while concurrently measuring their performance and effectiveness as essential components of organization's success (Chow et al., 2008). These and other challenges mean the Public Universities have to embrace change since new opportunities and challenges have and will continue to surface.

\subsubsection{University of Nairobi}

The foundation of the University of Nairobi can be traced back to 1947 when the then colonial Government in Kenya put forward a proposal for the creation of a commercial and technical institute in Nairobi. By 1949, it had matured to encompass the three East African countries namely Kenya, Tanzania and Uganda with the intention of providing specialized education for the member countries (UON, 2018). The Royal Technical College of East Africa was issued with a Charter in September of 1951. Around the same time, the Asian Community in the region was also working toward establishing an academy for Commerce, Science and Arts, in commemoration of Mahatma Gandhi. To prevent the replication of efforts, the society spearheading the Gandhi Memorial Academy conceded to work with the colonial Governments of East Africa. As a result in April of 1954, the Gandhi Memorial Academy was integrated into the Royal Technical College of East Africa, and by April of 1956, the college opened its doors to receive the first group of students. (UON, 2018).

The Royal Technical College was elevated to become the second University College in East Africa under the name Royal College Nairobi in 1961. In 1970, the University College Nairobi became the first national university in Kenya and was renamed the University of Nairobi (UON, 2017). As at December 2018, the university had a population of 84,000 students, 2,220 academic staff with PhDs and 5,525 administrative and technical staff (UON, 2018).

\subsection{Statement of the Problem}

Knowledge and skills possessed by an organization's workforce are becoming more and more important to its performance competitiveness, through continuous training (Ubeda-García, 2013: 380; Salas and Cannon-Bowers, 2001; Kraiger, 2003; Pena and Villasalero, 2010) and should be incorporated in policies as well as a focus for targeted local intervention (OECD, 2017). The success of any organizations is highly dependent of the quality of its employees (Mzimela \& Chikandiwa, 2017: 1) hence, the need to constantly update the employees' knowledge, skills and competencies. This approach emphasizes the importance of congruence between human resource activities and organizational objectives. It is also believed that human resource management is one of the main organizational factors influencing employment relationship at the organization level (Lv and Xu, 2016; Restubog et al., 2015). On a similar note, employee's service relationship with the organization is shaped by the human resource practices such as recruiting, training, performance appraisal and benefits administration (Rousseau and Greller, 1994) in addition to employee promotions and labour-management participation teams that also contribute to employee development thereby enhancing employee retention (Santhanam et al, 2017; Huselid, 1995. The need for better performance pay and improvement of the quality of work life by employees in academic institutions prompted the researcher to embark on carrying out an investigation into the influence of training and internal promotion incentives on employee performance at the University of Nairobi.

The objective of the paper is to examine examines the influence of training and internal promotion on employee performance at the University of Nairobi.

\subsection{Research Hhypothesis}

i) $\quad \mathrm{H}_{1}$ : The existing of training and skill development influences on performance in University of Nairobi.

ii) $\mathrm{H}_{1}$ : There is positive effect of internal promotion on performance in University of Nairobi. 


\subsection{Conceptual Framework}

The figure above is a conceptual framework derived from the set of four innovative HRM practices. The relationship between the various variables is shown and the possible outcome.

\section{Figure 1.1 Conceptual Framework}

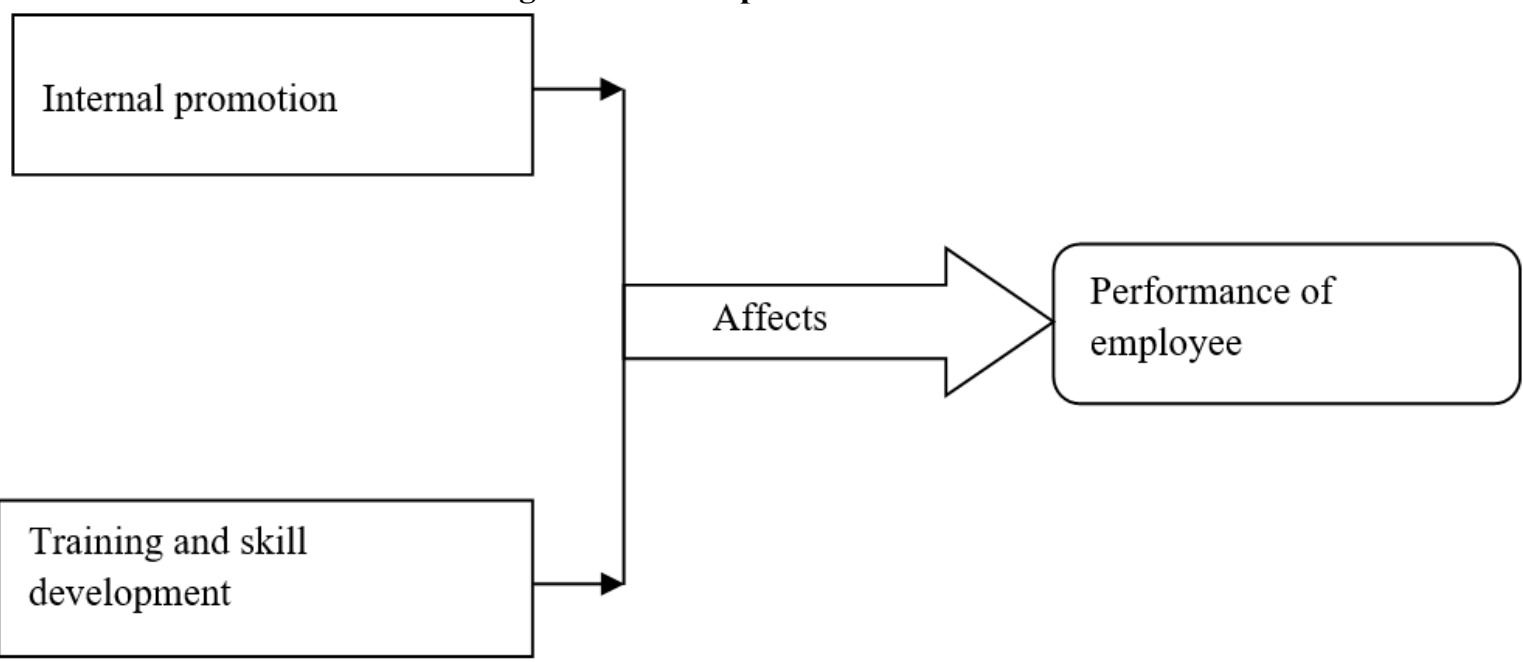

\section{Independent variable}

\section{Dependent variables}

The figure above is a conceptual framework derived from the set of two innovative HRM practices. The relationship between the various variables is shown and the possible outcome, whereby internal promotion positively affects employees work performance. Additionally training and skills development contribute to employees work performance.

\section{Review of the literature}

Developing economies require effective labour and Human Resource Development for national economic competitiveness, social well-being and political democracy (Riechi, 2010). According to Armstrong (2016), human resources management as defined as a strategic and coherent approach of the management of an organization's most valued assets, the people working there who individually and collectively contribute to the achievement of its goals. Storey (2013), on the other hand defines it as a distinctive approach to employment management which seeks to obtain competitive advantage through the strategic deployment of a highly committed and skilled workforce, using an array of cultural, structural and personal techniques.

Human resources management practices and systems have been linked to organizational competitiveness, increased productivity, higher quality of work life and greater profitability (Schuler, 2002). In a global economy, competitiveness means the ability to take the most advantageous position in a constantly changing market environment (Pfeffer, 1994). In order for this link to be accomplished between human resources management and organizational success, the role of human resources management must become strategic instead of operational, aligning the human resources function with the strategic needs of the organization (Pickles et al; 1999).

Performance measurement is an essential component of whatever change process is adopted. It can give feedback on the effectiveness of the plans and their implementation (Chow et al., 2008). Both business managers and accountants are keenly aware of the important role performance measurement plays in an organization's planning and control system. Reporting on firms' past performance is one of the fundamental uses of performance measurement system. Traditionally, the focus of performance measurement has been on financial measures such as sales growth, profits, return on investments and cash flows. There is, however, increasing concern among business managers on the over-reliance of financial measures in performance evaluation.

There are a growing number of managers within the public sector who now reason that if employee performance results in enhanced organizational performance, then employees should share in the benefits received. In other words, they feel that workers should be appropriately and equitably rewarded for their effort (Ghosh, 2005). It has been observed that when employees perceive that the only ones benefiting from their diligent efforts are the management team, shareholders, or other parties, they become discouraged. To avoid this, some managers have introduced reward packages in which employees receive enhanced pay based on individual and/or group performance (Mathias, \& Jackson, 2004). 


\subsection{Internal promotion}

Internal promotion is generally seen as a critical way to retain key members of the workforce (Srivastava etal 2008). Having recruited, developed and trained the 'right sort of people', it is unlikely that managers want to see these workers leave the organization. However, if managers are seeking short-term results and high profits, internal promotion may be a less appealing option (Torrington et al 2005). In instances where individuals are promoted from within they are more likely to have a thorough understanding of operational and other relevant aspects of the organizational environment. Also, promoting from within the organization is likely to perpetuate a 'favorable' organizational culture (Torrington et al 2005). As the above review highlights, the eight 'innovative' HR practices may not be appropriate in all settings, but core practices may be essential in gaining improved performance. The study findings will outline the proposed impact these practices have on individual performance outcomes, namely trust, commitment, satisfaction and labour turnover (Rao, 2005).

A promotion is a move up the organizational ladder; job rotation and transfers are lateral moves; demotions are downward moves; and layoffs move employees out. Layoffs, in contrast to dismissals (Elena, 2000), are terminations, sometimes temporary, required for business needs unrelated to worker behavior or performance. All of these changes bring about shifts in status, and often in pay, of the employees involved.

Despite the importance of promotion systems, relatively little is known about them beyond the work done on CEO succession: a very specific promotion decision (Forbes and Piercy, 1991; Vancil, 1987). The research that has been conducted on promotion systems has tended to focus on the promotion decision itself, not on the characteristics of the system. Thus, despite their importance as a principal vehicle of mobility in organizations and a mechanism for identification and control of talent and ability, we know surprisingly little about the mechanisms and causes of promotion systems in organizations.

Estimating the effect of both promotions and promotion expectations on job satisfaction helps us to understand the importance of promotions as a mechanism for eliciting greater effort from workers (Elena, 2000). Specifically, finding that promotions lead to greater job satisfaction, even after controlling for wages and wage increases, supports the notion that workers value the promotion itself. This gives firms a non-pecuniary tool for extracting effort and other positive behavior from their workers. Accurate estimates of these effects provide an indication of how effective promotions might be in eliciting effort. Furthermore, promotion expectations can also play a powerful role. Workers who realize they are not going to win a promotion this time around may decrease work effort, unless they believe they are still in the hunt for a future promotion.

\subsection{Training and skills development programmes}

Training and development is a subsystem of an organization that emanate from two independent yet interdependent words training and development. Training is often interpreted as the activity when an expert and learner work together to effectively transfer information from the expert to the learner (to enhance a learner's knowledge, attitudes or skills) so the learner can better perform a current task or job. Training activity is regarded as a key element of human resource (HR) management practice and the source for the enterprise to gain a sustainable competitive advantage (Randall \& Ian, 1984). Training has diverse benefits to employees: higher job satisfaction (Chiang et al., 2005), commitment to the organization (Ahmad \& Bakar, 2003) and reduced turnover intention (Newman et al., 2011), increase productivity, flexibility and quality and increased performance (Guan \& Frenkel, 2019).

Previous studies indicate a positive link of training towards organizations' productivity (Barrett \& O'Connell, 2001; Zwick, 2006), financial performance (Glaveli and Karassavidou, 2011; Kim \& Ployhart, 2014), innovative performance (Sung \& Choi, 2014) and sustainable development (Ji et al., 2012). At the individual level, several studies have demonstrated a similar link of training and employee performance (Bartel, 1994; Elnaga \& Imran, 2013; Khan, 2012). Training has been referred to as employee development, human resource development, and learning and development (Harrison, 2005). Personal training and career development programmes have been used by many successful public sector companies as a way of ensuring they have a ready pool of labour within the organization. If undertaken in a coherent and integrated manner, the training programmes can help secure the commitment of workers who are able to visualize their current and future roles in the organization (Mondy, 2005).

It is also proposed that when organizations undergo programmes of change, they should up-date the skills and expertise of new and existing workers. Following such training programmes, managers will then need to review current working practices, systems and processes to ensure that newly trained employees are able to utilize their skills effectively. Failing to undertake such a review may result in the anticipated benefits of the training programmes being lost (Pawan et al 2001).

Whereas employee training generates new knowledge, making it a continuous activity plays a significant role in the development of individual and organizational performance (Vemic, 2007; Ubeda-García, 2013; Salas and Cannon-Bowers, 2001; Kraiger, 2003; Pena and Villasalero, 2010). The strategic procedure of employee training and development needs to encourage creativity, ensure inventiveness and shape the entire organizational knowledge that provides the organization with uniqueness and differentiates it from the others (Vemic, 2007). 
Training employees therefore plays a critical role towards achieving organizations goals and objectives.

Following programmes of change many 'high performing' organizations strive to re-train or re-deploy staff, in order not to lose them. For instance, Robbins (2005) observed that a manufacturing company underwent a significant up-grade of its working systems and introduced new IT systems. Rather than recruiting candidates from the external labour market, the company focused on developing the skills of the existing workforce. This signaled to the workforce that the company was serious about looking after them, and this in turn led to the company receiving positive benefits in terms of increased staff morale, numbers of employee suggestions, better qualified workers and lower absenteeism and labour turnover rates. Therefore, training and skill development programmes appear to have a range of positive effects on organizational performance, especially when integrated with the overall business objectives.

\section{Methodology}

This is a descriptive study examining the influence of training and internal promotion on staff performance at the University of Nairobi. According to Gray (2004), descriptive research involves collecting data in order to answer questions concerning the current status of the subject under study, namely the influence of training and internal promotion on employee performance.

\subsection{Population and sample size}

The target population in this study was the non-teaching staff of the University of Nairobi. The study population therefore covered all the employees in the middle grades (Grades A - F). The population size for this category of staff was 1318 as per the University of Nairobi Establishment Plan, 2012. Based on Krejcie and Morgan table (1970), extracted from the division of the National Educational Association Schedule published formula 'Small Sample Techniques', the sample size for this study was 297 based on the population size of 1318, as indicated the figure below.

Figure 3.1 Population and sample size

\begin{tabular}{|l|l|r|}
\hline Category of population & Population size & Sample size (22.5\% of Population) \\
\hline A & 157 & 35 \\
\hline B & 79 & 18 \\
\hline D & 52 & 12 \\
\hline E & 52 & 12 \\
\hline F & 19 & 4 \\
\hline AB & 8 & 2 \\
\hline BC & 163 & 37 \\
\hline CD & 12 & 3 \\
\hline EF & 78 & 18 \\
\hline ABC & 80 & 18 \\
\hline DEF & 299 & 67 \\
\hline TOTAL & 319 & 71 \\
\hline
\end{tabular}

The researcher used primary data to carry out the study. This was done through administering closed-ended questionnaires, by use of structured questions based on the study's objectives. The researcher emailed the questionnaires to the subjects. The questionnaires were used to examine the influence of training and internal promotion on employee performance at the University of Nairobi.

According to Laws et al (2013), a questionnaire is a written list of questions, either given or posted to respondents, who fill it by themselves. Information is gathered directly from people through a series of questions, many which are likely to offer the respondent some possible replies to tick. Questionnaires are commonly used to obtain important information about the population. Each item in the questionnaire is developed to address a specific objective, or research question of the study. The researcher must also know how information obtained from each question item will be analyzed (Mugenda \& Mugenda, 2003).

A pretest piloting was used to test validity and reliability. The internal validity ensured relevance, consistency and coherence of results in relation to the researcher's objectives. The external validity enabled extrapolation of results from sample to other elements. In order to conduct an in-depth study and acquire an acceptable or precise degree of reliability and validity, the researcher used different sampling techniques to select the population sample. When selecting or sampling, the aim is to get a sample that is as representative as possible of the target population (Mouton, 1996:110). This was actualized by adopting the probability sampling method. This enabled the researcher to utilize some form of random selection which ensured that different units in the population have equal probabilities of being chosen. The researcher also applied stratified sampling technique. The stratified sampling technique produces estimates of overall population parameters with greater precision than estimates 
obtained from other sampling techniques. Additionally, purposive sampling was also applied to select from the target population in the university. The study then used convenient non probability sample since study units are easily accessible.

\subsection{Data analysis and discussion of findings}

The analysis was based on the data collected by use of questionnaires which were administered to respondents. This paper also presents an in-depth analysis of the findings using frequencies, percentages, mean scores, standard deviations and regression analysis. The research was conducted on a sample of 297 respondents from University of Nairobi. However, only 240 questionnaires were returned duly filled in making a response rate of $80.8 \%$, which is above the recommended 50\% by some scholars such as Rubin \& Babbie (2016:191) and Mugenda and Mugenda (2003). Additionally Babbie (2011:289) concurs that a 50\% response rate is acceptable and adequate for analysis and reporting, however $60 \%$ is believed to be good while above $70 \%$ is considered to be excellent, meaning the response rate for this study was above excellent.

The positive response rate was made possible after the researcher personally administered the questionnaires and made further visits to remind the respondents to fill-in the questionnaires. This study made use of frequencies (absolute and relative) on single response questions. On multiple response questions, the study used Likert scale in collecting and analysing the data whereby a scale of 5 points were used in computing the means and standard deviations. These were then presented in tables, graphs and charts (tables have been presented as appendix after the references, while graphs and charts have been excluded in this paper) as appropriate with explanations being given in prose. The analysis is based on the objective that seeks to find out the extent to which financial incentives contributed to employee performance at the University of Nairobi.

\subsection{Data analysis, interpretation and discussion}

Data collected was subjected to quantitative methods of analysis and interpreted by using frequency table percentages means and degrees whereby an in-depth analysis of the findings was done using frequencies, percentages, mean scores, standard deviations and regression analysis.

For part of the questionnaire that tested perceptions of the despondence, the Likert summated rating scale was used. Responses were rated on weighted values ranging from 1 to 5 or 1 to 7, e.g. 1 represented the most disagreed and 5 or 7 represented most agreed suggestion. The comparison was made based on the percentages, means, degrees and weighted values on the Likert Scale. Interpretations, inferences and conclusion were finally made based on the analyzed data based on the following regression model:

$y=\beta_{0}+\beta_{1} X_{1}+\beta_{2} X_{2}+e$, Where:

$\mathrm{y}=$ Employee performance of care staff

$\beta_{0}=$ Constant Term

$\beta_{1}=$ Beta coefficients

$\mathrm{X}_{1}=$ Internal promotion

$\mathrm{X}_{2}=$ Training and skill development programmers

e- Error term

\subsection{Demographic information}

This section provides the demographic information of the respondents. This includes the gender, age, work experience and the rank of the respondents.

\subsection{Gender}

From the analysis it is very clear that majority of employees are female. There were $57.6 \%$ female as compared to the male who are $42.3 \%$, which may be argued that the University of Nairobi practices equal opportunity employment for both genders as per the constitution of Kenya employment act Cap 226 (2012) and International Labour Organization (ILO, 2018) requirements. 
Figure 4.1: Gender

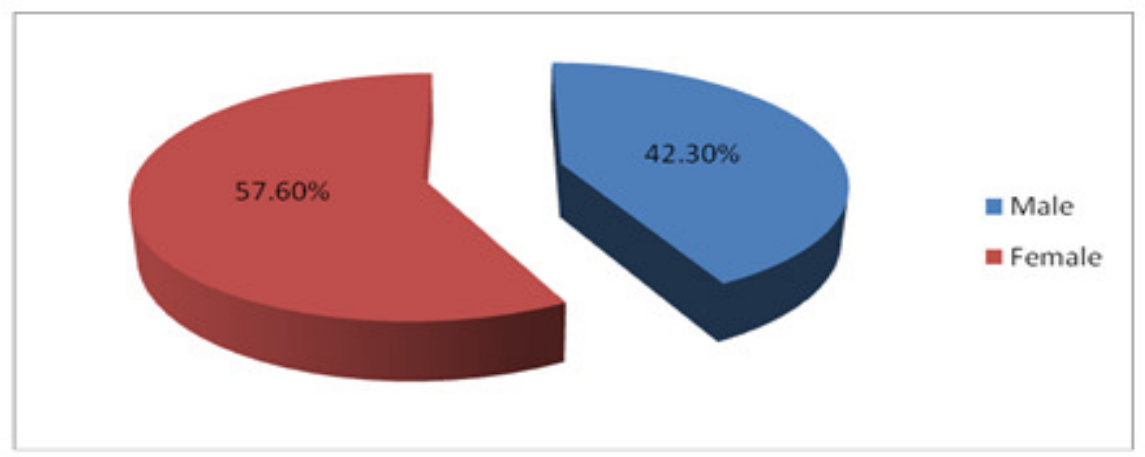

\subsection{Age}

Most of the respondents were youth under the age of 35 years. That is $36.8 \%$ of the respondents were between 26 and 35 years, $18.3 \%$ were between 36 and 45 years while $26.7 \%$ were between 18 and 25 years, $12.8 \%$ were between 46 and 55 years while the rest $5.4 \%$ were above 55 years. This age distribution was indicative that majority of UON staff are young and the middle aged and most active people in society. This is significant in any organization and may further be argued from Senge's perspective that an organization is a living community of people with shared responsibilities for effectiveness (Fulmer and Keys, 1998:35). See figure 4.2 below.

Figure 4.1: Age

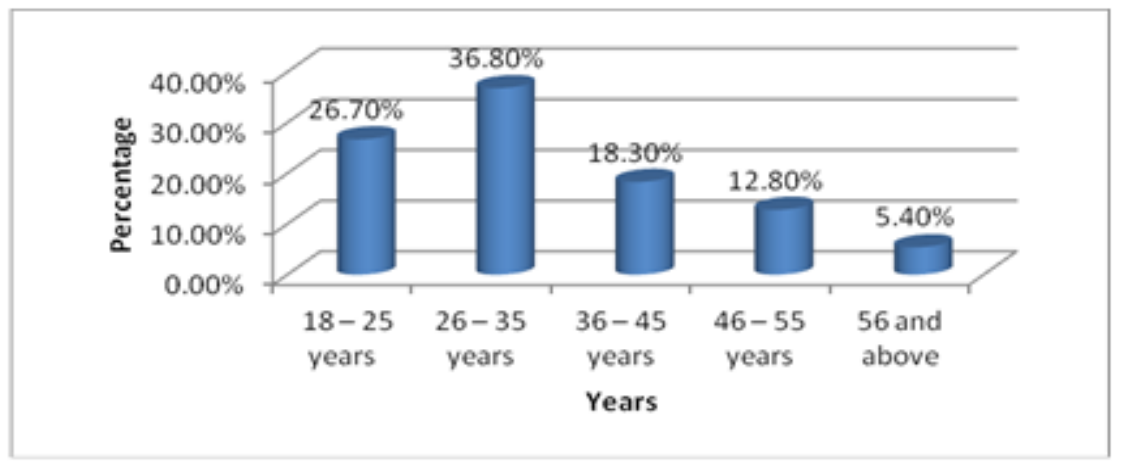

\subsection{Work Experience}

The figure below: 4.3 shows the work experiences of the staff members in years. From the findings, most $(45.8 \%)$ of the respondents stated having worked University of Nairobi for aperiod between 4-7 years. $22.4 \%$ indicated that they had worked University of Nairobi for a period of 8-12 years. The findings are therefore, indicate that majority of the staff members had a work experience of between 4-7 years, perhaps because majority of the staff members are young people as shown in figure 4.2. Experienced employees are more efficient and effective hence higher productivity. This confirms with Rynes et.al, (1997; Goldsmith \& Veum (2002); Quinones et al. (1995), who observed that work experience may improve performance. Additionally experienced workers tend to bring on board diverse knowledge that enables innovation and performance (Almeida et al. 2003; Rao \& Drazin 2002).

Figure 4.2: Work Experience

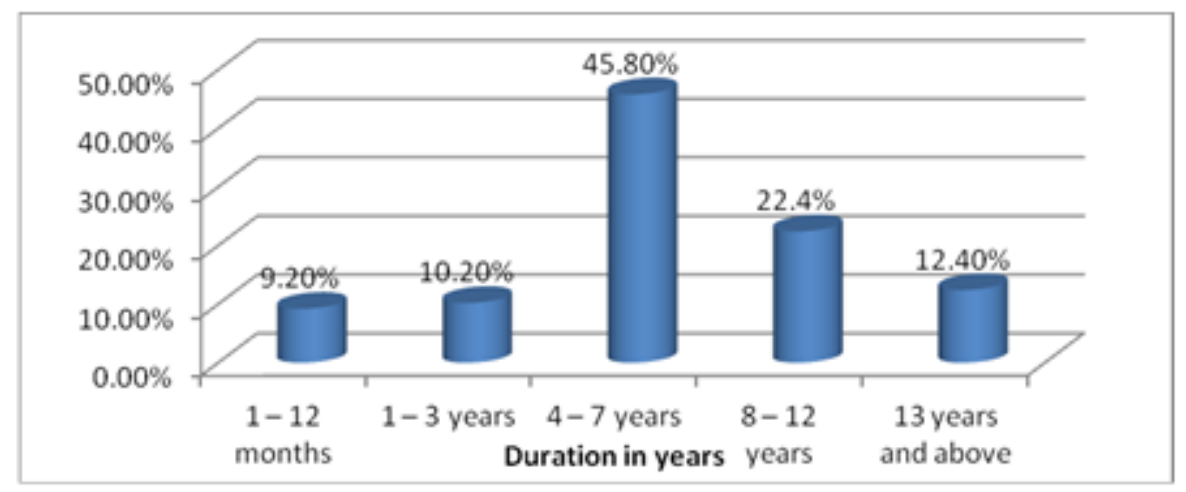




\subsection{Performance of University staff}

The study sought to establish the extent to which employee performance measures used in the organization. The response was rated on a Likert scale of 1 to 5 where I represented strongly disagree, $2=$ disagree, 3 neutral, 4= Agree and 5= strongly agree. The result is illustrated in table 4.1 below.

Table 4.1: Employee performance measures

\begin{tabular}{|l|r|r|}
\hline & Mean & Std. Dev \\
\hline Innovation and change & 4.0969 & 0.72685 \\
\hline Customer satisfaction & 4.0996 & 0.60704 \\
\hline Operating efficiency & 4.0893 & 0.57885 \\
\hline Financial performance & 4.1047 & 0.50373 \\
\hline
\end{tabular}

The findings in the table 4.1 above show that majority of the respondents agree that the organization upholds performance measure which include financial performance $(\mathrm{M}=4.1047, \mathrm{SD}=0.50373)$, customer satisfaction $(\mathrm{M}=4.0996, \mathrm{SD}=0.60704)$, innovation and change $(\mathrm{M}=4.0969, \mathrm{SD}=0.72685)$ and Operating efficiency $(\mathrm{M}=4.08937, \mathrm{SD}=0.57885)$.

The respondents were further requested to indicate your level of agreement with the statements in figure below regarding the influence of job performance of university staff.

Table 4.3: Influence of job performance of university staff

\begin{tabular}{|l|c|c|}
\hline & Mean & $\begin{array}{c}\text { Std. } \\
\text { Deviation }\end{array}$ \\
\hline Employees in this organization are recognized fairly & 3.4439 & 0.91205 \\
\hline Evaluation of employee's performance in this organization is carried out fairly & 3.9679 & 0.81905 \\
\hline Employees' personal milestones are recognized in this organization & 4.1589 & 0.44621 \\
\hline $\begin{array}{l}\text { Compensation awarded to employees is fair and competitive according to industry } \\
\text { standards }\end{array}$ & 3.8936 & 0.7282 \\
\hline This organization contributes a sufficient amount for healthcare costs of employees & 4.0321 & 0.53073 \\
\hline $\begin{array}{l}\text { This organization addresses life problems that get in the way of employees } \\
\text { performance }\end{array}$ & 3.9841 & 0.64018 \\
\hline You are motivated to do your best when working for this organization & 3.9957 & 0.79482 \\
\hline Your personal objectives match with those of the organization & 4.0085 & 0.79053 \\
\hline You are planning to pursue any professional advancement & 4.1967 & 0.58421 \\
\hline
\end{tabular}

The study findings in table show that majority of the employees are planning to pursue any professional advancement $(\mathrm{M}=4.1967, \mathrm{SD}=0.5842)$ which is indicated by a higher mean and complemented by standard deviation clustered around the mean $(\mathrm{SD}<1)$. Employees also agreed that their personal milestones are recognized in $\operatorname{UoN}(\mathrm{M}=4.1589, \mathrm{SD}=0.44621)$. Evaluation of employee's performance in the organization is carried out fairly $(M=3.9679, S D=0.81905)$, and that their personal objectives matched with those of the organization $(M=4.0085$, $\mathrm{SD}=0.79053)$. Besides, majority of the respondents agreed that the organization contributes a sufficient amount for healthcare costs of employees $(\mathrm{M}=4.0321, \mathrm{SD}=0.53073)$, they are motivated to do their best when working for the organization $(\mathrm{M}=3.9957, \mathrm{SD}=0.79482)$. The organization addresses life problems that get in the way of employees performance $(\mathrm{M}=3.9841, \mathrm{SD}=0.64018)$ and compensation awarded to employees is fair and competitive according to industry standards $(\mathrm{M}=3.8936, \mathrm{SD}=0.7282)$. Majority of the respondents expressed moderate view in regards to fair recognition of employees in the organization are recognized fairly $(\mathrm{M}=3.4439$, $\mathrm{SD}=0.91205)$.

\subsection{Internal promotion}

The study aimed at establishing whether internal promotion enhances performance of university staff. The findings are presented in figure below. 
Figure 4.4: Internal promotion and performance

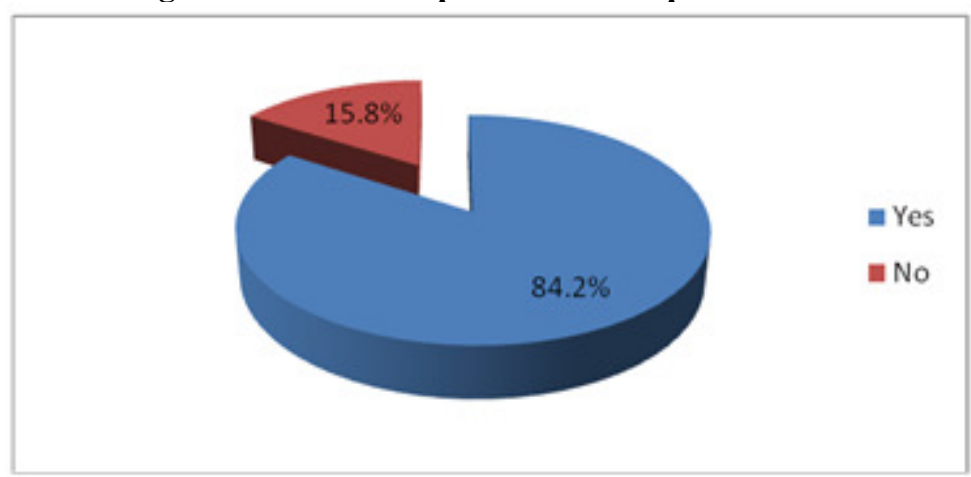

The findings in figure above indicate that majority of the respondents $(84.2 \%)$ of the respondents agreed that internal promotion enhances performance of university staffs and the remaining $15.8 \%$ disagreed. The respondents were further requested to indicate the extent to internal promotion enhances performance of university staffs. The findings are presented in figure below. The response was rated on a Likert scale of 1 to 5 where I represented very low extent, $2=$ low extent, 3 moderate extent, $4=$ great extent and $5=$ very great extent.

Figure 4.5: The extent to which internal promotion enhances performance

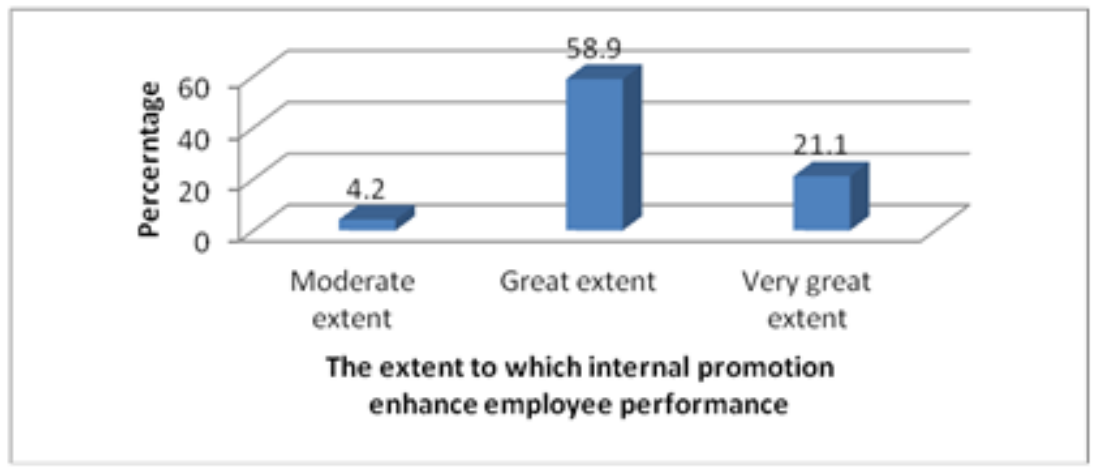

The study findings presented in figure above indicate that majority of the respondents $(58.9 \%)$ agreed that internal promotion enhances performance to a great extent. $21.1 \%$ of the respondents said that internal promotion enhances performance to a very great extent while a few respondents $(4.2 \%)$ of the respondents who indicated that internal promotion enhances performance to a low extent.

A further investigation was done on the extent to which internal promotion enhances performance. The respondents were requested to indicate their level of agreement with the following statements in regard to the influence of employment promotion on performance of employees. The responses were rated on a Likert scale of 1 to 5 where 1 represented strongly disagree, $2=$ disagree, $3=$ neutral, $4=$ agree and strongly agree. The findings are presented in table below.

Table 4.6: Influence of internal promotion on performance

\begin{tabular}{|l|c|c|}
\hline & Mean & $\begin{array}{c}\text { Std. } \\
\text { Deviation }\end{array}$ \\
\hline $\begin{array}{l}\text { If workers are given the impression that they are dispensable, they increase their } \\
\text { output. }\end{array}$ & 1.8211 & 0.48332 \\
\hline Workers who have been promoted have a self-confidence that enhances performance. & 4.1579 & 0.44521 \\
\hline Proper procedures on internal promotion ensures increased employees' performance. & 4.0526 & 0.3681 \\
\hline $\begin{array}{l}\text { Internal promotion enhances retention of highly qualified staff thus increase } \\
\text { organizational productivity. }\end{array}$ & 4.2421 & 0.43063 \\
\hline $\begin{array}{l}\text { Internal promotion results to a thorough understanding of organizational operations and } \\
\text { work environment which increases performance. }\end{array}$ & 3.8842 & 0.65009 \\
\hline $\begin{array}{l}\text { Promoting from within the organization is likely to perpetuate a favorable } \\
\text { organizational culture. }\end{array}$ & 4.0421 & 0.52422 \\
\hline
\end{tabular}

The mean (average) and standard deviation (square root of the variance) of the responses were computed and the findings presented in table above. Majority of the respondents agreed that Internal promotion enhances retention of highly qualified staff thus increase organizational productivity $(\mathrm{M}=4.2421 \mathrm{SD}=0.43063)$, Workers who have been promoted have a self-confidence that enhances performance ( $M=4.1579$ SD0.44521), Proper procedures on internal promotion ensures increased employees' performance $(\mathrm{M}=4.0526 \mathrm{SD}=0.3681)$, Promoting 
from within the organization is likely to perpetuate a favorable organizational culture $(\mathrm{M}=4.0421 \mathrm{SD}=0.52422)$, Internal promotion results to a thorough understanding of organizational operations and work environment which increases performance $(\mathrm{M}=3.8842 \mathrm{SD}=0.65009)$. However majority of the respondents disagreed to the statement that If workers are given the impression that they are dispensable, they increase their output $(\mathrm{M}=1.8211$ $\mathrm{SD}=0.48332$ ).

\subsection{Training and skill development programmes}

The study sought to establish whether training and skill development programmes enhanced performance of university staff. Figure below shows the findings.

Figure 4.7: Whether training and skill development programmes enhanced performance

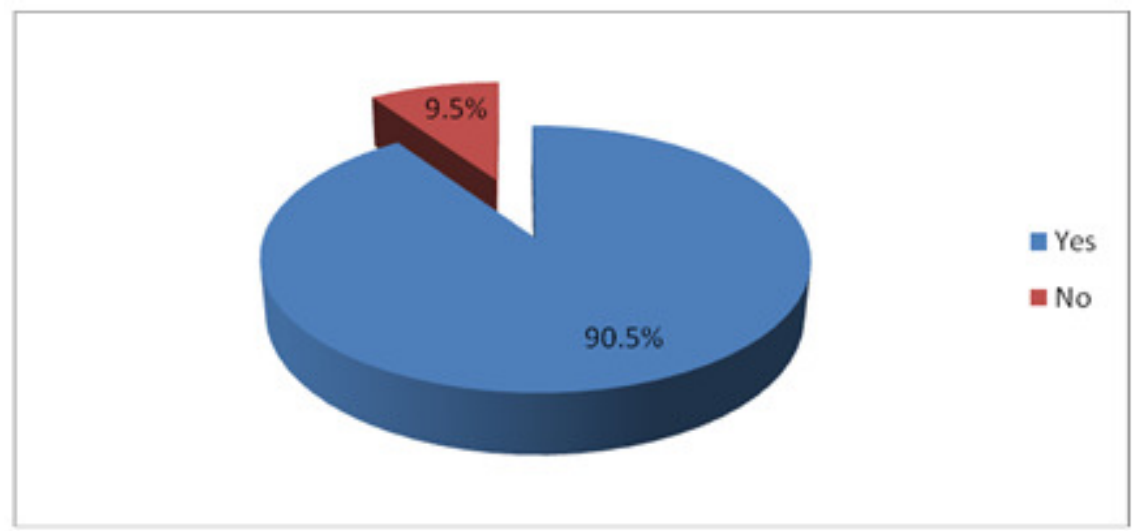

According to the findings, majority of the respondents $(90.5 \%)$ indictaed that training and skill development programmes enhanced performance. Only $9.5 \%$ of the respondents indicated that training and skill development programmes did not enhance performance. This confirms findings from previous studies indicating that training elicits positive work attitudes from employees including job satisfaction (Chiang et al., 2005), self-efficacy (Axtell and Parker, 2003) and organizational commitment (Ahmad and Bakar, 2003).

Besides, the respondents were requested to indicate the extent to which training and skill development programmes enhanced performance. The response was rated on a Likert scale of 1 to 5 where I represented very low extent, $2=$ low extent, 3 moderate extent, $4=$ great extent and $5=$ very great extent. The findings are presented in figure below.

Figure 4.8: The extent to which training and skill development influence performance

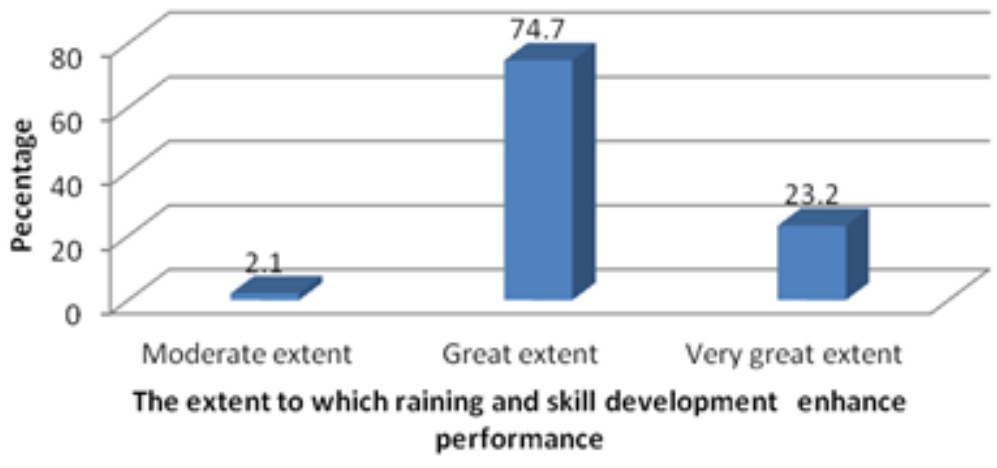

According to the findings, majority of the respondents $(74.7 \%)$ indicted that training and skill development programmes enhanced performance of university staff to a great extent. In addition $23.2 \%$ said that training and skill development programmes enhanced performance to a very great extent while $2.1 \%$ indicated that it affected performance to a moderate extent, which also concurs to previous studies (Bednall et al., 2014).

The respondents were also asked to indicate their level of agreement with the following statements regarding the influence of training and skill development programmes on performance. The responses were rated on a Likert scale of 1 to 5 where 1 represented strongly disagree, $2=$ disagree, $3=$ neutral, $4=$ agree and strongly agree. Table shows the findings. 
Table 4.9: Influence of training and skill development programmes on performance

\begin{tabular}{|l|l|l|}
\hline & Mean & $\begin{array}{l}\text { Std. } \\
\text { Deviation }\end{array}$ \\
\hline $\begin{array}{l}\text { Training programmes can help secure the commitment of workers leading to better } \\
\text { performance }\end{array}$ & 4.1579 & 0.44521 \\
\hline $\begin{array}{l}\text { Training imparts up-to-date information which enhances employee knowledge and } \\
\text { skills for better performance }\end{array}$ & 4.1895 & 0.4201 \\
\hline $\begin{array}{l}\text { Training helps managers review current working practices, systems and processes } \\
\text { to ensure that employees perform to expectations }\end{array}$ & 4.0315 & 0.53584 \\
\hline $\begin{array}{l}\text { Training ensures a ready pool of highly required labour within the organization } \\
\text { which results in sustainable performance. }\end{array}$ & 4.0105 & 0.55534 \\
\hline $\begin{array}{l}\text { Training ensures development and retention of highly qualified and productive } \\
\text { employees }\end{array}$ & 3.9789 & 0.54537 \\
\hline
\end{tabular}

From the findings presented in table above, the respondents agreed that training imparts up-to-date information which enhances employee knowledge and skills for better performance $(\mathrm{M}=4.1895 \mathrm{SD}=0.4201)$ training programmes can help secure the commitment of workers leading to better performance $(\mathrm{M}=4.1579$ $\mathrm{SD}=0.44521$ ), training helps managers review current working practices, systems and processes to ensure that employees perform to expectations $(\mathrm{M}=4.0315 \mathrm{SD}=0.53584)$, training ensures a ready pool of highly required labour within the organization which results in sustainable performance $(\mathrm{M}=4.0105, \mathrm{SD}=0.55534)$ and training ensures development and retention of highly qualified and productive employees as shown by a mean of $(\mathrm{M}=3.9789 \mathrm{SD}=0.54537)$.

\subsection{Employee performance of university staff}

The study sought to determine the general extent to which HRM enhances performance of university staff. The response was rated on a Likert scale of 1 to 5 where I represented very low extent, $2=$ low extent, 3 moderate extent, $4=$ great extent and $5=$ very great extent. The findings are presented in figure below:

Figure 4.3: General extent to which HRM practices enhance performance

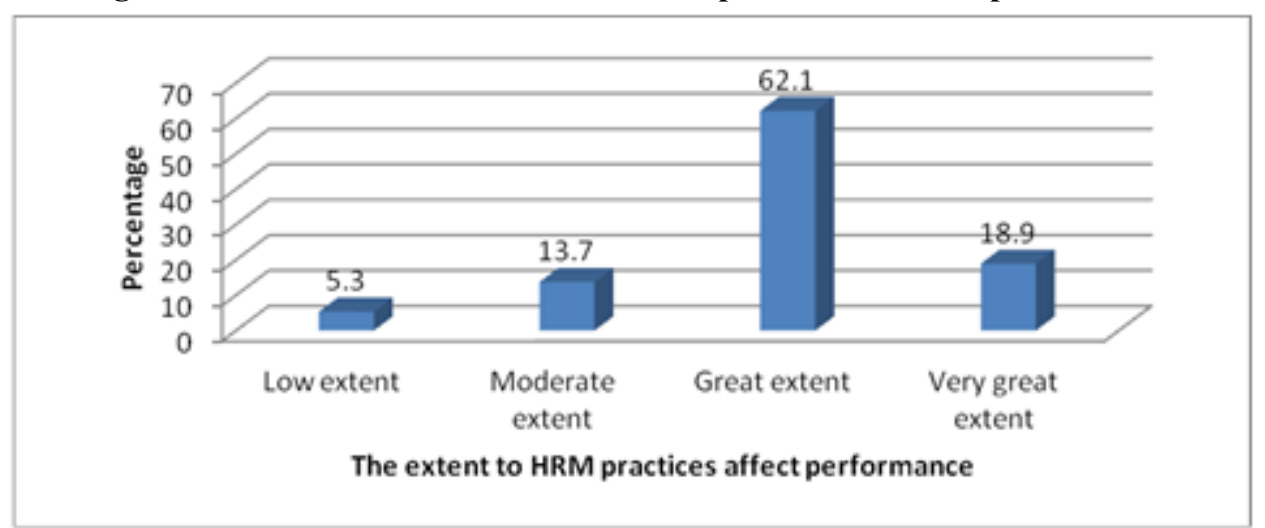

According to the findings, majority of the respondents (62.1\%) indicted that HRM practices affect performance to a great extent. On the other hand, $18.9 \%$ said that HRM practices affect performance to a very great extent, $13.7 \%$ to a moderate extent while $5.3 \%$ indicted that HRM practices affect performance to a low extent.

The respondents were further requested to indicate their generl view on the impact of on human resource management practices on enhancing performance. The responses were rated on a Likert scale of 1 to 5 where 1 represented strongly disagree, $2=$ disagree, $3=$ neutral, $4=$ agree and strongly agree. Table below shows the study findings.

Table 4.11: General extent to which HRM practices enhance performance

\begin{tabular}{|l|l|l|}
\hline & Mean & Std. Deviation \\
\hline Internal promotion & 3.8316 & 0.76704 \\
\hline Training and skill development programmes & 4.0737 & 0.58786 \\
\hline
\end{tabular}

The findings in table above reveals that majority of the respondents generally agree that human resource management practices such as internal promotion, training and skill development programmes enhance performance $(\mathrm{M}=3.8316,4.0737)$ with a standard deviation of 0.76704 and 0.58786 respectively. While these findings may conform to previous studies ( $\mathrm{Ng}$ and Siu, 2004; Nguyen et al., 2011), other studies do not such as Newman et al. (2011) who found that learning motivation and the perceived benefits of training do not impact organizational commitment and performance of service employees. 


\subsection{Regression analysis}

The researcher performed a regression analysis to establish the association between the independent variables with the dependent variables. The findings are shown in the table.

The regression model was as follows:

$y=\beta_{0}+\beta_{1} X_{1}+\beta_{2} X_{2}+e$

Where:

$\mathrm{y}=$ Employee performance of university staff

$\beta_{0}=$ Constant Term

$\beta_{1}=$ Beta coefficients

$\mathrm{X}_{1}=$ Internal promotion

$\mathrm{X}_{2}=$ Training and skill development programmes

\subsection{1: Strength of the model}

Analysis in table 4.3.1 shows that the coefficient of determination (the percentage variation in the dependent variable being explained by the changes in the independent variables) R2 equals 0.843 , that is, Training and skill development programmes, internal promotion leaving only 15.7 percent unexplained. The P-value of 0.000 (Less than 0.05) implies that the model of Employee performance of university staff is significant at the 5 percent significance.

Table 4.12: Model Summary

\begin{tabular}{|ll|r|r|r|r|r|}
\hline \multicolumn{1}{|c|}{} & Sodel & Sum of Squares & df & Mean Square & \multicolumn{1}{|c|}{ F } & Sig. \\
\hline 1 & Regression & 93.144 & 4 & 23.286 & 79.730 & $.000^{\text {a }}$ \\
& Residual & 53.739 & 56 & .292 & & \\
& Total & 146.884 & & & & \\
\hline
\end{tabular}

a. Predictors: (Constant), Training and skill development programmes, Internal promotion

b. Dependent Variable: Employee performance of university staff

ANOVA findings ( $\mathrm{P}$ - value of 0.00 ) in table 4.12 show that there is correlation between the predictor's variables (Training and skill development programmes, Employee satisfaction, and internal promotion) and response variable (Employee performance of university staff). An F ratio is calculated which represents the variance between the groups, divided by the variance within the groups. A large F ratio indicates that there is more variability between the groups (caused by the independent variable) than there is within each group, referred to as the error term (Pallat, 2007). A significant F test indicates that we can reject the null hypothesis which states that the population means are equal.

Table4.131: Coefficients of regression equation

Coefficients $^{\mathrm{a}}$

\begin{tabular}{|c|c|c|c|c|c|}
\hline \multirow[t]{2}{*}{ Model } & \multicolumn{2}{|c|}{$\begin{array}{c}\text { Unstandardized } \\
\text { Coefficients }\end{array}$} & \multirow{2}{*}{$\begin{array}{c}\text { Standardized } \\
\text { Coefficients } \\
\text { Beta }\end{array}$} & \multirow[b]{2}{*}{$t$} & \multirow[b]{2}{*}{ Sig. } \\
\hline & $\mathrm{B}$ & Std. Error & & & \\
\hline 1 (Constant) & .240 & .258 & & .930 & .354 \\
\hline Internal promotion & .294 & .077 & .297 & 3.798 & .000 \\
\hline $\begin{array}{l}\text { Training and skill development } \\
\text { programmes }\end{array}$ & .421 & .077 & .406 & 5.445 & .000 \\
\hline
\end{tabular}

a. Dependent Variable: Employee performance of university staff

The established multiple linear regression equation becomes: $\mathrm{Y}=0.240+0.294 \mathrm{X}_{1}+0.230 \mathrm{X}_{2}+0.421 \mathrm{X}_{3}$

\section{Where}

Constant $=0.240$, shows that if Training and skill development programmes, Employee satisfaction, Internal promotion all rated as zero, Employee performance of university staff would be 0.240

$\mathrm{X}_{1}=0.294$, shows that one unit change in Internal promotion results in 0.294 units increase in Employee performance of university staff

$\mathrm{X}_{2}=0.421$, shows that one unit change in Training and skill development programmes results in 0.421 units increase in Employee performance of university staff 


\subsubsection{Coefficient Correlations}

\section{Table 4.14: Coefficient Correlations}

\begin{tabular}{|l|l|l|l|}
\hline Correlations & $\begin{array}{l}\text { Employee performance of } \\
\text { university staff }\end{array}$ & $\begin{array}{l}\text { Internal } \\
\text { promotion }\end{array}$ & $\begin{array}{l}\text { Training and skill } \\
\text { development programmes }\end{array}$ \\
\hline $\begin{array}{l}\text { Employee performance of } \\
\text { university staff }\end{array}$ & 1.000 & 0.753 & 0.704 \\
\hline Internal promotion skill & .753 & 1.000 & .051 \\
\hline $\begin{array}{l}\text { Training and } \\
\text { development programmes }\end{array}$ & .051 & 1.000 \\
\hline
\end{tabular}

Dependent Variable: Employee performance of university staff

The correlation analysis produced shows e provision of training and other skill development programmes were positive correlated as shown with 0.753 . The findings indicate that provision of training and other skill development programmes and internal promotion are positively correlated (0.051).

\subsubsection{Test of hypothesis}

i) $\quad \mathrm{H}_{1}$ : There is positive effect of internal promotion on performance in University of Nairobi.

ii) $\quad \mathrm{H}_{1}$ : The existing of training and skill development influences on performance in University of Nairobi.

Table 4.2: Hypothesis testing

\begin{tabular}{|l|l|l|}
\hline Hypothesis & $\begin{array}{l}\text { Coefficient } \\
\text { Values }\end{array}$ & Conclusion \\
\hline $\begin{array}{l}\mathrm{H}_{1} \text { : There is positive effect of internal promotion on performance in } \\
\text { University of Nairobi }\end{array}$ & $\mathrm{P}=0.000<=0.05$ & $\begin{array}{l}\text { Accept } \mathbf{H}_{1 .} \\
\text { Reject } \mathbf{H}_{\mathbf{0}}\end{array}$ \\
\hline $\begin{array}{l}\mathrm{H}_{1}: \text { The existing of training and skill development influences on } \\
\text { performance in University of Nairobi }\end{array}$ & $\mathrm{P}=0.000<=0.05$ & $\begin{array}{l}\text { Accept } \mathbf{H}_{1 .} \\
\text { Reject } \mathbf{H}_{\mathbf{0}}\end{array}$ \\
\hline
\end{tabular}

\subsection{Summary of findings}

The following highlights, briefly provides the study's summary of findings:

\subsection{Internal promotion}

The findings on the influence of internal promotion on performance indicate that internal promotion largely enhances performance of university staff. Besides, internal promotion enhances retention of highly qualified staff thus increase organizational productivity. Findings also show that workers who have been promoted have a selfconfidence that enhances performance, proper procedures on internal promotion ensures increased employees' performance, promoting from within the organization is likely to perpetuate a favorable organizational culture, internal promotion results to a thorough understanding of organizational operations and work environment which increases performance. However, use of approaches which create impression that workers are dispensable do not increase their output.

\subsection{Training and skill development programmes}

The findings on the influence of training and skill development programmes on performance revealed that that training and skill development programmes enhanced performance of university staff to a greater extent. Training imparts up-to-date information that enhances employee knowledge and skills for better performance. Additionally it can help in securing commitment of workers leading to better performance. Moreover, training helps managers review current working practices, systems and processes to ensure that employees perform to expectations and ensures a ready pool of highly required labour within the organization which results in sustainable performance, development and retention of highly qualified and productive employees.

\subsection{Conclusion}

The study findings on performance measure indicate that University of Nairobi upholds performance measure such as customer satisfaction, innovation and change and operation efficiency. Regarding the extent to which employee performance measures used in the organization, the study found that evaluation of employee's performance in the organization is carried out fairly, employees' personal milestones are recognized in the organization. The findings also indicate that mmajority of the respondents were planning to pursue professional advancement and that their personal objectives matched with those of the organization.

Besides, the findings show that employees are motivated to do their best when working for the organization, the organization addresses life problems that get in the way of employees performance and compensation awarded to employees is fair and competitive according to industry standards. However, there was a moderate view from the respondents in regards to fair recognition of employees in the organization are recognized fairly.

In an organization, employees need to reach optimum performance levels, especially when many of them are cross-trained to perform distinctly different job functions. The study revealed that the performance measures in 
the University of Nairobi were mainly on areas of innovation and change, customer satisfaction, operating efficiency and financial performance. The components are used to measure how well the workforce is performing.

On the influence of human resource management practices on staff performance, the study revealed that internal promotion greatly affects employee performance, it enhances retention of highly qualified staff thus increase organizational productivity. It was also noted that those workers who have been promoted have a selfconfidence that enhances performance and promoting workers from within the organization is likely to perpetuate a favorable organizational culture.

Training and development is another factor that was found by the study to greatly influence employee performance. Training programmes can help secure the commitment of workers leading to better performance. It also imparts up-to-date information which enhances employee knowledge and skills for better performance and helps managers review current working practices, systems and processes to ensure that employees perform to expectations. Training also ensures a ready pool of highly required labour within the organization which results in sustainable performance. This is in agreement with previous studies that found out training contributed to higher job satisfaction (Chiang et al., 2005), commitment to the organization (Ahmad and Bakar, 2003) and reduced turnover intention (Newman et al., 2011).

From the findings, the study finds that well-rewarded employees feel their organization values them. This motivates them to be more dedicated and committed to their employer when their well-being is prioritized. The more the employees are motivated the more they perform (Giancola, 2011; Hansen, etal, 2012). Organizations that implement such practices with dedication, maintain a competitive edge over their competitors because such practices affect other variables such as competitive advantage, job satisfaction, financial performance, employee turnover, service quality, employee commitment in a positive manner and leads to an improved overall corporate performance. Since this study indeed established that incentive training and promotion is a key human resource factor that has tremendous effect on the employee performance, then organizations should venture into these factors in order to maintain competitive advantage. It is also imperative to conclude that based on this study, there is positive effect of internal promotion and trainings as incentives on employee performance at the University of Nairobi.

\subsection{Recommendations}

The paper recommends the following:

- Human resource management practices should be prioritized if the organizations aim at increasing its general performance.

- Focus on the teaching fraternity especially on both intrinsic and extrinsic incentives towards enhanced academic and research productivity.

- The University management conducts continuous and consistent incentivized-based training programs for all employees to achieve an ultimate increased employee performance.

- The paper also highlights the importance of internal promotion, therefore a merit-based internal promotion as form of reward to its employees, which in turn improves employee performance, should be considered.

\subsection{Limitations and future research directions}

The study's limitations justify suggestions for further research. The first limitation is the lagged timeline since the data was collected in 2012. There is need for an updated research with revised instruments, but inclined to the category of the teaching employees.

Largely the study focused on the influence of training and internal promotion of employees as a motivation for their performance. There are contrary debates that do not agree to this school of thought and suggestions for further research into the retrogressive implication of these two initiatives, including the previous research that pegged employee performance on financial incentives (see Njiraine, 2019).

Additional research to explore the role of emerging trends, in terms of technologies, environment (facility layout, location, and supervision), attitude (character) and other personal (family issues) as other factors that affect employee's performance is recommended.

\section{REFERENCES}

Ahmad, K. \& Bakar, R. (2003). The association between training and organizational commitment among whitecollar workers in Malaysia. International Journal of Training and Development, 7 (3), 166-185.

Almeida, P., Dokko, G.,Rosenkopf, L. (2003). Startup size and the mechanisms of external learning: Increasing opportunity and decreasing ability? Res. Policy 32(2), 301-315.

Armstrong, M (2016). Armstrong's handbook of human resource management. London: Kogan Page.

Atambo, W; Kabare, K; Munene, C \& Mayogi, E. (2013). The role of employee incentives on performance:

A survey of public hospitals in Kenya. Global Business and Economics Research Journal, 2 (12), 29-44.

Axtell, C. \& Parker, S. (2003). Promoting role breadth self-efficacy through involvement, work redesign and training. 
Human Relations, 56 (1), 113-131.

Babbie, E. (2011). The basics of social research, 5th ed. Belmont: Wadsworth.

Barrett, A. \& O'Connell, P. (2001). Does training generally work? The return to in- company training. Industrial and Labor Relations Review 54(3), 647-663.

Bartel, A. (1994). Productivity gains from the implementation of employee training programs. Industrial Relations, 33, $411-425$.

Bednall, T., Sanders, K. \& Runhaar, P. (2014). Stimulating informal learning activities through perceptions of performance appraisal quality and human resource management system strength: A two-wave study. Academy of Management Learning \& Education, 13 (1), 45-61.

Beer, M., et al (2005). Human resource management: A general manager's perspective. 6th edition, Free Press, New York.

Boxall P \&Purcell, J. (2016). Strategy and human resource management. London: Palgrave Macmillan.

Campbell, D. (2008). Nonfinancial performance measures and promotion-based incentives. Journal of Accounting Research, 46 (2), 297-332.

Chiang, C., Back, K. \& Canter, D. (2005). The impact of employee training on job satisfaction and intention to stay in the hotel industry. Journal of Human Resources in Hospitality \& Tourism, 4 (2), 99-118.

Chow, W., Christin, N., Chu-Hua, K., Min, H., Chinho, L. \& Hojung, T. (2008). Supply Chain Management in the US and Taiwan: An empirical study. Omega, 36 (5), 665-679.

Coff, R., \& Kryscynski, D. (2011). Invited editorial: Drilling for micro-foundations of human capital-based competitive advantages. Journal of Management, 37, 1429-1443.

Commission for Universities Education. (2017). Universities authorized to operate in Kenya. Retrieved from http://www.cue.or.ke/index.php/status-of-universities.

Commission for University Education. (2017). Accredited universities in Kenya-March 2017: Nairobi List of universities:

Retrieved

from http://www.cue.or.ke/images/phocadownload/Accredited Universities in Kenya November 2017.pdf

Datta, D., Guthrie, J. \& Wright, P. (2005). Human resource management and labor productivity: Does industry matter? Academy of Management Journal, 48, 135-145.

Elena P. (2000). Employee development through self-development in three retail banks. Journal of Personnel Review, 29 (4), 491-508.

Elnaga, A. and Imran, A. (2013). The effect of training on employee performance. European Journal of Business and Management, 5 (4), 137-147.

Elmer, b. (1988). Public service and the public interest. Public administration review, 48 (2), 601.

Foss, N. J. (2011). Invited editorial: Why micro-foundations for resource-based theory are needed and what they may look like. Journal of Management, 37, 1413-1428.

Fulmer \& keys (1998). A conversation with Peter Senge: New developments in organizational learning. Organisational dynamics, 27 (2), 33-42. Online. Science direct database. Accessed 03 mar 2019.

Ghosh, B. (2005). Human resources development and management, $5^{\text {th }}$ edition. New Delhi: Vikas Publishing House PVT Ltd.

Giancola, F. (2011). Examining the job itself as a source of employee motivation. Compensation and Benefits Review, $43(1), 23-29$.

Glaveli, N. \& Karassavidou, E. (2011). Exploring a possible route through which training affects organizational performance: The case of a Greek bank. The International Journal of Human Resource Management, 22 (14), 2892-2923.

Goldsmith, A. \& Veum, J. (2002). Wages and the composition of experience. Southern Econom. J. 69 (2) 429 443.

Gould-Williams, J. (2004). The effects of 'high commitment' HRM practices on employee attitude: The views of public sector workers. Public Administration, 82 (1), 63-81.

Guan, X \& Frenkel, S. (2019). How perceptions of training impact employee performance: Evidence from two Chinese manufacturing firms. Personnel Review, (48), 163-183.

Gray, D. E. (2004). Doing research in the real world. London: Sage Publications.

Government of Kenya. (2010). Employment Act, Cap. 226. Nairobi: Kenya Government Printer.

Hansen, F., Smith, M. \& Hansen, R. (2012). Rewards and recognition in employee motivation. Compensation and Benefits Review, 34 (5), 64-72.

Harrison, R (2005). Learning and Development. NP: Chartered Institute of Personnel and Development Publishing.

Huselid, M. (1995). The impact of human resource management practices on turnover, productivity, and corporate financial performance. Academy of Management Journal, 38 (3), 635-872.

International Labour Organization. (2018). World employment social outlook: Trends 2018. Geneva: Document and Publications Production.

Ji, L., Huang, J., Liu, Z., Zhu, H., \& Cai, Z. (2012). The effects of employee training on the relationship between 
environmental attitude and firms' performance in sustainable development. The International Journal of Human Resource Management, 23 (14), 2995-3008.

Kaiser, L. (2014). Job satisfaction and public service motivation. IZA discussion paper no. 7935,

January 2014 (Bonn: Forschungsinstitut zur zukunft der arbeit (Institute for the Study of Labour).

Kim, Y. \& Ployhart, R.E. (2014). The effects of staffing and training on firm productivity and profit growth before, during and after the Great Recession. Journal of Applied Psychology, 99 (3), 361-389.

Krejcie, R., \& Morgan, D. (1970). Determining sample size for research activities. Educational and Psychological Measurement, 30, 607-610.

Kwambai B. J (2017). High student enrolment and its implication on teaching and learning in selected public universities in Kenya. IOSR Journal of Research \& Method in Education (IOSR-JRME), 7 (5), 61-66.

Kwon, K., \& Rupp, D. E. (2013). High-performer turnover and firm performance: The moderating role of human capital investment and firm reputation. Journal of Organizational Behavior, 34 (1), 129-150.

Laws, S., Harper, C., Jones, N. \& Marcus, R. (2013). Research for development: A practical guide. 2nd ed. London: SAGE Publications.

Lawzi, M. (1995). Individuals' attitudes working in public institutions in Jordan towards job incentives. Derasat, Humanities Studies, 22a (6), 759-785.

Lepak, D. P., Liao, H., Chung, Y., \& Harden, E. E. (2006). A conceptual review of human resource management systems in In J. Martocchio (Ed.), Strategic human resource management research: Research in personnel and human resource management, (25:217-271). Greenwich, CT: JAI.

Liao, H., Toya, K., Lepak, D. P. \& Hong, Y. (2009). Do they see eye to eye? Management and employee perspectives of high-performance work systems and influence processes on service quality. Journal of Applied Psychology, 94: 371-391.

Ling, L., Qing, T, \& Shen, P, (2014). Can training promote employee organizational commitment? The effect of employability and expectation value, Nankai Business Review International, 5 (2), 162-186.

Lv, Z. \& Xu, T. (2016). Psychological contract breach, high-performance work system and engagement: The mediated effect of person-organization fit, The International Journal of Human Resource Management, 1-28.

Mathias, R \& Johnson, J. (2004). Human resource management. Thomson, South-Western: Mason Publishers.

Mouton, J. (1996). Understanding Social Research. Pretoria: Van Schaik.

Mugenda, O \& Mugenda A. (2003). Research methods, quantitative and qualitative approaches. Nairobi: Acts Press.

Mullius, L. J (2005). Management and organizational behaviour, $7^{\text {th }} \mathrm{Ed}$.

Mzimela, T \& Chikandiwa, C. (2017). Employee training and development practices in the tourism and leisure sector in KwaZulu-Natal, South Africa. African Journal of Hospitality, Tourism and Leisure, 6 (4), 1-17.

Newman, A., Thanacoody, R. \& Hui, W. (2011). The impact of employee perceptions of training on organizational commitment and turnover intentions: A study of multinationals in Chinese service sector. The International Journal of Human Resource Management, 55, 1765-1787.

Ng, Y. \& Siu, N. (2004). Training and enterprise performance in transition: Evidence from China. The International Journal of Human Resource Management, 15 (4/5), 878-894.

Nguyen, T., Truong, Q. \& Buyens, D. (2011). Training and firm performance in economies in transition: A comparison between Vietnam and China. Asia Pacific Business Review, Vol. 17 (1), 103-119.

Nyangau, J. (2014). Higher education as an instrument of economic growth in Kenya. FIRE: Forum for International Research in Education, 1(1): 7-25.

Ogutu, W. (2014). Perception of the influence of incentives on employee job performance in the Ministry of Education in Kenya. Unpublished Dissertation. UoN Repository.

OECD. (2009). Internationalization of Higher Education: A Policy Brief. Ojiambo: OECD.

Okioga, C.; Onsongo, E. \& Nyaboga, Y. (2014). Quality issues in the expansion of university education in Kenya, The human resource challenges and opportunities', Chinese business review, Vol. 11, No. 6, Pp. 596-605.

Onsongo, J. (2007). The growth of private universities in Kenya: Implications for gender equity in higher education. JHEA/RESA, 5 (2\&3), 111-133

Pallat, J. (2007). SPSS survival manual: Step by step guide to data analysis using SPSS for widows (3 ${ }^{\text {rd }}$ ed.). England: Open University Press.

Pena, I., \&Villasalero, M. (2010). Business strategy, human resources system, and organizational performance in the Spanish banking industry. International Journal of Human Resource Management, 21, 2864-2888.

Pfeffer, J., (1994). The human equation building profits by putting people first. London: Harvard Business Press.

Pickles, L., Bookbinder, S. \& Watt, C. (1999). Building the HR value chain. Employment Relations Today, 25 : 21-23.

Purcell, J. (2004). The HRM-performance link: why, how and when does people management impact on organisational performance? John Lovett Memorial Lecture: University of Limerick.

Quinones, M., Ford, J \& Teachout, M. (1995). The relationship between work experience and job performance: 
A conceptual and meta-analytic review. Personnel Psych. 48 (4) 887-910.

Rao, H., \&. Drazin, R. (2002). Overcoming resource constraints by recruiting talent from rivals: A study of recruitment and product innovation in the mutual fund industry 1986-1994. Acad. Management J. 45 (3) 491-507.

Rehman, R \& Ali, M A. (2013). Is Pay For Performance The Best Incentive For Employees? Journal of Emerging Trends in Economics and Management Sciences, 4 (6), 512-514.

Restubog, S., Zagenczyk, T.Bordia, P., Bordia, S. \& Chapman, G. (2015). If you wrong us, shall we not revenge? Moderating roles of self-control and perceived aggressive work culture in predicting responses to psychological contract breach. Journal of Management, 41 (4), 1132-1154.

Riechi, A. (2010). Demand for regular academic programs offered in Kenya's universities and their relevance to the labor market. Discussion Paper, No, 113.

Rubin, A. \& Babbie, E. (2016). Essential research methods for social work. Australia: Cengage Learning.

Rynes, S., Orlitzky, M \& Bretz, R. (1997). Experienced hiring versus college recruiting: Practices and emerging trends. Personnel Psych. 50 (2) 309-339.

Salas, E \& Cannon-Bowers, J. (2001). The science of training: A decade of progress. Annu. Rev. Psychol, 52, 471-99

Santhanam, N., Kamalanabhan T., Dyaram, L. \& Ziegler, H. (2017). Impact of human resource management practices on employee turnover intentions: Moderating role of psychological contract breach. Journal of Indian Business Research, 9 (3), 212-228.

Schuler, R. (2002). Linking competitive strategies with human management Practices. Academic of Management Executive, 1(3), 209-213.

Staats, E. (1988). Public service and the public interest. Public Administration Review, 48 (2), 601-605.

Sung, S. \& Choi, J.N. (2014). Multiple dimensions of human resource development and organizational performance. Journal of Organizational Behavior, 35, 851-870.

Storey, J. (2013). Human Resource Management. New York, NY: McGraw-Hill.

Takeuchi, R., D. P. Lepak, H. Wang, \& K. Takeuchi. (2007). An empirical examination of the mechanisms mediating between high-performance work systems and the performance of Japanese organizations. Journal of Applied Psychology, 9 2(4), 1069-1083.

Torrington et al. (2005). Human Resource Management. England: Pearson Education limited.

UNDP. (2006). Incentive Systems: incentives, motivation and development performance. nd: Conference Paper Series Production Team, Capacity Development Group.

Úbeda-García, M., Marco-Lajara, B., Sabater, V.\& Garcia-Lillo, F. (2013). Training policy and

organisational performance in the Spanish hotel industry. International Journal of Human Resource Management. 24 (15), 2851-2875.

University of Nairobi. (2012). University of Nairobi Establishment Plan 2012.

University of Nairobi. (2018). UON Profile: Background. Retrieved February 06, 2018, from http://www.uonbi.ac.ke/about/profile

International Labour Organization. (2018). World employment social outlook: Trends 2018. Geneva: Document and Publications Production.

Vancil R. (1987). Passing the baton: Managing the process of CEO Succession. Boston:

Harvard Business School Press.

Vemic, J. (2007). Employee training and development and the learning organization. Economics and Organization, $4,(2), 209-216$.

World Bank. (2017). Higher education for development: An evaluation of the World Bank group's support. Washington: World Bank Publications.

Zwick, T. (2006). The impact of training intensity on establishment productivity. Industrial Relations, 54 (1), 26-46.

\section{Author}

Dorothy Njiraine is the Chairperson and Lecturer, Department of Library and Information Science, University of Nairobi, Kenya. She holds a Doctorate of Library and Information Science (University of Zululand, South Africa2011), MSc. in Information Science (Makerere University, Uganda-2005), MBA (Moi University, Kenya-2012), PGD in Librarianship (Makerere University, Uganda- 1998) and B.A. Hons (University of Nairobi, Kenya- 1989). She is also a member of Kenya Library Association.

Research interests: Knowledge management; Indigenous knowledge; Indigenous knowledge systems; ICT4D; Agricultural information and communication management; Digital libraries and information systems; Management information systems; Information literacy and communication skills Information ethics; Informetrics; Strategic management; Human resource management; Project planning and management; Research methods. 